\title{
Editorial
}

\section{O futuro da revista}

Jean Louis Peytavin, editor executivo jeanlouis@atlanticaeditora.com.br

Após quase 10 anos de existência, a revista Fisioterapia Brasil se adapta progressivamente às novas condiçôes de difusão e publicação científicas.

O padrão clássico de revista impressa não corresponde mais à velocidade esperada da comunicação, e a solução da revista eletrônica, tão usada no dia a dia do ensino e da pesquisa, não mostrou ainda como encontrar um equilíbrio financeiro aceitável. No entanto, apesar das dúvidas, o caminho está traçado: o futuro será virtual.

$\mathrm{O}$ apoio de nossos assinantes e autores foi determinante para garantir a difusão da revista e transformá-la em ferramenta indispensável da fisioterapia brasileira. Mas as suas limitaçôes são a cada dia mais evidentes: náo podemos publicar todos os trabalhos de qualidade que recebemos, pois aumentariam em demasia o tamanho da revista e, por conseguinte os custos de impressáo e correios.

Para melhorar a presença da revista em nosso meio e acelerar a publicação dos artigos, estamos trabalhando em duas direçōes. Na primeira, vamos continuar a melhorar a revista, que ganhará mais páginas, mas com uma difusão relativamente limitada. Na segunda, vamos desenvolver ferramentas de acesso à revista por Internet e propor novos serviços.

$\mathrm{O}$ acesso da revista por Internet significa que os assinantes que escolhem essa opção poderão receber a versáo eletrônica da revista, igual à versão impressa, no formato pdf. A vantagem é que o preço da assinatura anual estará significativamente reduzido, por causa da eliminação dos custos da versão impressa*. Segunda vantagem: a revista estará disponível com um mês de antecedência em relação à revista impressa.

Os novos serviços que pretendemos oferecer são a continuação do projeto inicial da revista, que queria ser uma ferramenta de pesquisa e também de ensino. Com o tempo, privilegiamos sempre os trabalhos acadêmicos e pesquisas de campo, úteis para o pesquisador, o professor e o pósgraduando, mas um pouco distante da realidade profissional. Por isso, o novo portal da revista vai apresentar módulos de ensino, ajudando no aprimoramento de todos os profissionais, no dia-a-dia do consultório e da clínica.

Esses novos serviços serão desenvolvidos em parceria com a Atlântica Educacional, líder da pós-graduação lato sensu em Fisioterapia, que já formou milhares de especialistas e pode disponibilizar a experiência de seus 200 professores**.

Assim, os assinantes da Fisioterapia Brasil, receberão, por um preço reduzido, uma revista mais atualizada, mais ágil, e terão condiçốes privilegiadas para acessar nossos módulos de treinamento.

Recomendamos a todos os assinantes interessados pela versão pdf entrar em contato conosco, pelo e-mail: atlantica@ atlanticaeditora.com.br, a fim de confirmar o seu endereço eletrônico atual.

\section{Notas}

* Mais informaçôes em nosso site www.atlanticaeditora.com.br, ou por telefone (21) 22214164 . A assinatura da versão eletrônica será feita exclusivamente pela Internet ou por telefone. Condiçôes especiais para as assinaturas que estão em andamento.

** A Atlântica Educacional é parceira de Atlântica Editora, mas as duas empresas são total e juridicamente distintas. A responsabilidade das publicaçôes e das assinaturas é inteiramente da Atlântica Editora. 